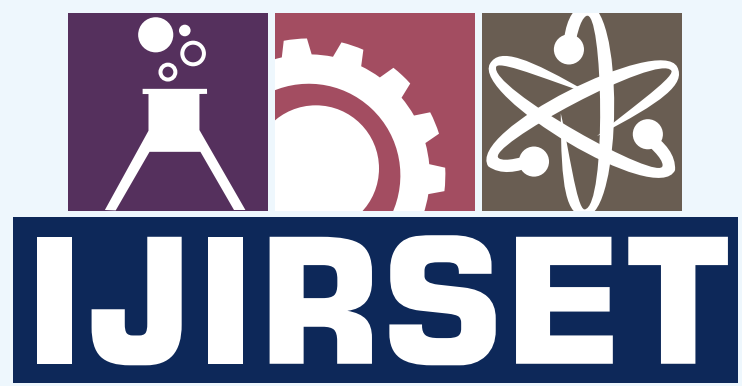

International Journal of Innovative Research in SCIENCE | ENGINEERING | TECHNOLOGY

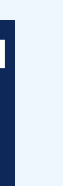

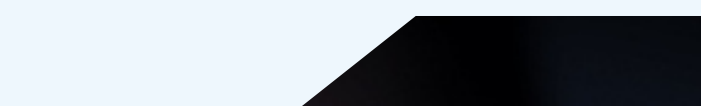

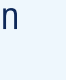




\title{
Students' Perception Towards e-learning through Online Sessions amidst Covid-19 Pandemic Situation
}

\author{
Dr.Rituparna Basak ${ }^{1}$, Papri Manna ${ }^{2}$ \\ Assistant Professor, Department of Psychology, Muralidhar Girls' College, Kolkata, India ${ }^{1}$ \\ State Aided College Teacher, Department of Psychology, Surendranath College, Kolkata, India ${ }^{2}$
}

\begin{abstract}
Present study aimed at finding out the college students' perception towards e-learning in respect of four domains i.e., perceived usefulness of e-learning, perceived ease of use of e-learning, attitude towards using e-learning $\&$ intention to use e-learning during this pandemic situation. Two random samples of 309 Undergraduate college students (152 males and 157 females) studying in several undergraduate degree colleges affiliated to Calcutta University were selected. Students' Perception of E-learning Questionnaire (R. S. Mamattah, 2016) along with a general information schedule were administered on selected samples through online. Findings suggest that the perception of e-learning partially varied according to certain study variables viz., gender, residing areas, using type of electronic gadgets, academic years \& educational programmes on the basis of four above mentioned domains.
\end{abstract}

KEYWORDS:students' perception, e-learning, pandemic situation.

\section{INTRODUCTION}

The Covid-19 pandemic has made a global impact in the past few months and continues to hit most of the sectors, with education being one of the most affected ones. Students across the world are losing valuable time in their education during the imposed lockdown amidst fears of pandemic. The situation has forced the schools \& colleges to shut down and the students to stay at home.

No wonder, the children as well as parents feel emotionally and psychologically drained at this juncture. At such a time, the extended lockdown period is forcing the education sector in India to rapidly evolve. Most educational institutions have come up with the idea of online classes for students to start their respective academic years, instead of wasting time due to the delay in reopening of institutions.

A learning system based on formalised teaching but with the help of electronic resources is known as E-learning. While teaching can be based in or out of the classrooms, the use of computers and the Internet forms the major component of E-learning. Terms such as "open education," "distance education," "distance learning," "virtual learning," "remote learning," "online learning," and "e-learning" are now part of educators' everyday lexicon. Use of such terminology helps to define and shape the creative innovations taking place. However, many overlaps can be seen within these terms. Urdan and Weggen (2000), for instance, found that online learning constitutes just one part of e-learning; and further define it as learning processes that take place via the Internet and in blended classroom contexts. They specified that e-learning covers a wide spectrum of applications and processes, including virtual classrooms and digital collaboration.

The term "e-learning," for example, has generated many different definitions according to Carry and Willis (2001), who broadly define e-learning as any form of learning that utilizes a computer or technological network for delivery, interaction, or facilitation. Becker (1991) opines that e-learning covers a wider set of applications and processes, which include Web-based learning and virtual classrooms. Hall and Snider (2000) define e-learning as the process of learning via computers over the Internet and Intranets. For the purposes of this article, the author will say that e-learning can be defined as "acquisition and use of information distributed and perceived by technological means."

E-learning comes in three different types - fully-online, mixed mode (also known as hybrid or blended learning), and web assisted (Anastasiades\&Retalis, 2001). In fully-online learning, there are no physical contacts between the learner and the instructor, everything is done fully-online through the use of internet and its technologies. Unlike in face-toface learning which enables face-to-face interaction, between learners and with instructors, in fully-online, this is not the case. Learning materials, assignments, teaching and learning are all done online (Young, et al, 2008). 
Hybrid learning, unlike fully-online learning, combines face-to-face meeting and interaction with online learning (Allen \& Seaman, 2003). In this type of e-learning, some aspects of the teaching and learning are done online, whiles some portions are done face-to-face.

Web-assisted mode is the last type of e-learning, and makes use of the synchronous tools, where course website and tools are used, in order to enhance teaching and learning. Web-assisted learning is operated much in the same as the fully-online class with the exception that it includes online discussions and interactions between the learners and the instructors.

Among the types of e-learning, hybrid learning (mixed mode) is thought to be a better approach (Davis, 2000), as it combines elements of fully-online learning or web-assisted learning with the traditional classroom learning (Rubenstein, 2003; Ward \&LaBranche, 2003). Furthermore, in the blended learning, students are allowed to read some of the course materials online prior to the face-to-face meeting, which allows the students to have a fair idea of the topic to be discussed in class (Smart \&Cappel, 2006).

In addition to the types of e-learning available, it is further classified into two forms - synchronous and asynchronous learning.

Synchronous Learning and Its Technologies: This form of learning is done in real-time with an instructor facilitating live discussions and lectures with students in the learning process. It includes- Audio conferencing, chat, instant messaging, video conferencing, web conferencing, white boarding, application sharing etc.

Asynchronous Learning and Its Tools: This form of learning involves self-paced or self-contained learning and offers greater flexibility than the synchronous learning approach. This flexibility gives participants a variety of options, allowing them to learn at their own pace and in their own time (Kocur\&Kosc, 2009). It includes- databases, document libraries, e-books, forums, messaging (e-mails), streaming audio, streaming video, blogs, website links etc. In contrast with synchronous learning (or a conventional classroom setting), this form of learning links participants to referenced materials instead of live, real time instructors (Kalpana, 2010).

\section{RELATED WORK}

The review of literature has shown various studies have been conducted to identify and assess perception $\&$ attitude of the e-learners towards e-learning. Student attitudes and beliefs towards e-learning, as well as their satisfaction with technology and past e-learning experiences are regarded as success determinants of future e-learning initiatives. While e-learning and its potential benefits for developing countries have already been acknowledged, research on user perspectives of e-learning in those countries is limited.

Many scholars agree that information \& communication technologies play an increasingly important role in facilitating the educational processes and systems of today (AL-Hunaiyyan, Al-Huwail, \& Al-Sharhan, 2008; Oh \& Park, 2009; Vaughan \& Garrison, 2006). E-learning has started to emerge in many developing countries where it has the potential to help meet an increasing demand for education and address the growing decline of trained teachers (UNESCO, 2006). The application of e-learning in developing countries has gradually advanced in recent years with an improved availability of Internet connections, local area networks, and IT support (Omidinia, Masrom, \&Selamat, 2011; Tedre, Ngubuke, \&Kempainnen, 2010; Williams, Mayer, \& Minges, 2011). However, other challenges still prevail. In those countries, the active, participative student who is required for interactive learning is rare, and the traditional methods are widely used in teaching and learning (Andersson\&Grönlund, 2009; Eastmond, 2000; Evans, 2005; Sehrt, 2003). In addition, the developing countries often lack the ability to implement advanced educational practices on their own (Andersson\&Grönlund, 2009).

Student characteristics are regarded as a critical success factor in e-learning in developing countries (Bhuasiri, Xaymoungkhoun, Zo, Rho, \&Ciganek, 2012). These characteristics include computer self-efficacy, Internet selfefficacy, computer experience, Internet experience, computer anxiety, and attitudes toward e-learning (Chu \& Chu, 2010; Chiu \& Wang, 2008; Fuller et al., 2006; Pituch\& Lee, 2006; Shih, Muñoz, \& Sanchez, 2006; Sun et al., 2008). Student attitudes are influenced by the quality and perceived ease of use of e-learning courses, functionality of elearning platforms, and the level of student computer skills (Aixia\&Wang; 2011). Their computer experience including perceived self-efficacy, enjoyment, and usefulness of using e-learning also plays a role (Liaw\& Huang, 2011). In turn, positive student attitudes and behaviors towards e-learning are critical to their e-learning readiness and acceptance (Lim, Hong, \& Tan, 2008; Selim, 2007).

Factors Influencing Students' perception towards ICT and E-learning:

Students' perception towards e-learning have been identified as critical to the success of e-learning (Zhang \& Bhattacharyya, 2008). Bhuasiri, Xaymoungkhoun, Zo, Rho and Ciganek (2012) found that in developing countries the most significant factors were related to increasing technology awareness and improving attitude toward e-learning, enhancing basic technology knowledge and skills, improving learning content, requiring computer training, motivating users to utilise e-learning systems, and requiring a high level of support from the university. In addition, attributes used to assess the attitudes towards ICT of students, teachers and principals have been categorised in two groups: 
demographics (age and gender) and computer experience (training, years of using computer, ownership of computer, access to a computer, intensity of computer use) (Jimoyiannis\&Komis, 2007; Papaioannou\&Charalambous, 2011; Wen \& Shih, 2008).

\section{- Demographic Characteristics:}

Literature shows that gender plays a key role in understanding the differences in perceptions of the usefulness of technology and attitudes and perceptions of e-learning; various studies have been undertaken to investigate the effect of gender, as well as age, and year of study on student attitudes (Bertea, 2009; Cheng, 2006; Paris, 2004; Roca, Chiu, \& Martinez, 2006). Several studies revealed that male students had more positive attitudes towards e-learning than female students (Liaw\& Huang, 2011; Papaioannou\&Charalambous, 2011; Whitley, 1996). In contrast to this, Egbo and colleagues (2011) concluded that female students tended to accept the use of ICT more than their male counterparts. Suri and Sharma (2013) found no gender differences in relation to the attitudes towards e-learning. These results are in line with some recent research studies which revealed that the gap between men and women (gender divide) is narrowing (Bhattacharjee, 2008; Gillwald, Milek, \& Stork, 2010; Imhof, Vollmeyer, \&Beierlein, 2007; Teo, 2008; UNESCO, 2012).

- Access to Technology :

Student levels of access to technologies represent an initial factor that would shape their perceptions towards e-learning, and their willingness to use it. According to Gulati (2008), the developing nations find the traditional means of learning more reliable and sustainable. However, Omidinia, Masrom and Selamat (2011) reported that the use of ICT technology for learning was widely accepted in Iran's educational institutions.

- Technology Use and Skills:

Over the last few decades there has been increased use of computing devices in educational institutions in developing countries (Deb, 2011; Trucano, Hawkins \& Iglesias, 2012). The use of the web, computer, and mobile-based technologies has drawn a lot of interest among students, who use them for educational purposes as well as for social networking. This at least implies a degree of familiarity with these technologies and the skills for using those (Trucano et al., 2012). As mentioned above, in Pakistan, the students' ability to use ICTs was significantly hindered by the low level of technology access (Hussain 2007). Many research studies identified correlations between positive computer experience and positive attitudes, competence and comfort with computers (Schumacher \&Morahan-Martin, 2001; Papaioannou\&Charalambous, 2011; Paris, 2004) and an inverse relationship between computer experience and computer anxiety (Busch, 1995; Olatoye, 2011).

- $\quad$ Satisfaction with Technology:

Student satisfaction with e-learning environments was examined in several studies (Santhanam, Sasidharan, \& Webster, 2008; So \& Brush, 2008; Wu, Tennyson, \& Hsia, 2010; Zhu, 2012). Positive learning climate and performance expectations affect student satisfaction, and performance expectations provide the greatest contribution (total effect) to learning satisfaction. Users (students and instructors) will hold positive perceptions towards e-learning if they recognise that it would help them improve their learning and teaching effectiveness and efficiency (Rahamat et al., 2012; Wu, Tennyson, \& Hsia, 2010). Wang (2011) found that the vast majority of students who were satisfied with an e-learning environment held positive believes and perceptions towards it; perceived satisfaction was identified as one of four factors that helped explain $83.8 \%$ of the variance of student attitude.

McKenzie (1998) said that technology would transform the act of teaching, whether or not teachers or students are ready for this inevitable change. According to McKenzie, when faced with new technology, students and/ or teachers would likely adopt one of two approaches: they would either embrace it or they would dismiss it. In other words, teachers and students will either learn how to use new technology, or they would ignore it - the latter of which would put them at disadvantage compared to their more technologically literate peers. For e-learning to take root and grow, a robust technical infrastructure must also be in place to support all the technical aspects necessary for the production of course materials, delivery of e-learning courses, and teacher and student support (Mason, 2001).

Considering the above, the present investigation had been aimed to study students' perception towards e-learning through online sessions during this pandemic situation. 


\section{Hypotheses:}

1. The male undergraduate honours students will significantly differ from female counterparts in respect of, perceived usefulness of e-learning, perceived ease of use of e-learning, attitude towards using e-learning \& intention to use e-learning.

2. Rural undergraduate honours students will significantly differ from their urban counterparts in respect of, perceived usefulness of e-learning, perceived ease of use of e-learning, attitude towards using e-learning \& intention to use e-learning.

3. Undergraduate honours students who use only mobile phones for e-learning \& those of their counterparts who use both mobile phones \& laptops/desktop for e-learning will significantly different from each other in respect of, perceived usefulness of e-learning, perceived ease of use of e-learning, attitude towards using e-learning \& intention to use e-learning.

4. There will be a significant difference in mean scores among three academic years in honours undergraduate degree course (i.e.; $1^{\text {st }}$ year, $2^{\text {nd }}$ year $\&$ final year) on the basis of- i) perceived usefulness of e-learning, ii) perceived ease of use of e-learning, iii) attitude towards using e-learning \& iv) intention to use e-learning, respectively.

5. There will be a significant difference in mean scores of three programmes in honours undergraduate degree course (i.e.; Science, Humanities \& Commerce) on the basis of- i) perceived usefulness of e-learning, ii) perceived ease of use of e-learning, iii) attitude towards using e-learning \& iv) intention to use e-learning, respectively.

\section{METHODOLOGY}

\section{Participants:}

A Web-based survey composed of a group of 309 Undergraduate college students (152 males and 157 females) studying in several undergraduate degree colleges affiliated to Calcutta University had been done during Covid-19 pandemic situation. Participants belonging to 18 to 21 years old are considered for the present study. All are undergraduate college students and their family structures are nuclear or semi-nuclear type and they belong to middle socio-economic status. Subjects with chronic physical and mental disorder were excluded by suitable screening through questions asked in general information schedule.

\section{Survey Instruments:}

General Information Schedule: It elicits information about socio-demographic variables like age, sex, education, domicile, family structure and family income etc.

Students' Perception of E-learning Questionnaire: This questionnaire was developed by Raymond SelormMamattah in 2016. The questionnaire has an introductory section providing information on the topic being researched and instructions for respondents filling the questionnaire was also included. The questionnaire comprised 21 questions, these were divided into five sub-sections: personal information; perceived usefulness of e-learning; perceived ease of use of e-learning; attitude toward using e-learning and finally, intention to use e-learning. Some items are rated on a 5point scale, some of them are on 3-point scale \& few are true-false items. There are certain reverse items also. Higher the scores are more positive attitude of students' perception towards e-learning. The questions were drafted in accessible language to ensure maximum understanding. Moreover, the preliminary testing of the questionnaire made it possible for necessary corrections to be made to ensure that the questionnaire was accessible and the available multiple choice answers allowed respondents to select an answer commensurate with their view. To achieve reliability, the questionnaire was framed in a clear way to avoid leading respondents or suggesting answers. Bias is an important threat to reliability (ibid) thus, to increase objectivity, the anonymity of the students who participated in the questionnaire was guaranteed.

\section{Collection of Data:}

Data were collected through web-based survey method from the undergraduate college students of Calcutta University during COVID-19 pandemic situation. Both male and female college students were approached online through mail and social networking sites. All the interested participants were provided online questionnaires through mails. 


\section{EXPERIMENTAL RESULTS}

The raw scores were calculated after collecting and scrutinized the data of the students of different colleges. The Means (M) and standards deviations (SD) of four domains of E-Learning data for male and female students were calculated and the results are presented in Table I.

Table I: Descriptive results of the domains in male and female students

\begin{tabular}{lcccc}
\hline \multicolumn{1}{c}{ Domains } & \multicolumn{2}{c}{ Male $(\mathrm{N}=152)$} & \multicolumn{2}{c}{ Female $(\mathrm{N}=157)$} \\
\cline { 2 - 5 } & Mean & SD & Mean & SD \\
\hline Perceived usefulness of e-learning & 22.07 & 3.502 & 22.06 & 3.611 \\
Perceived ease of use of e-learning & 23.39 & 4.030 & 22.55 & 3.633 \\
attitude toward using e-learning & 21.76 & 3.810 & 21.52 & 3.879 \\
Intention to use e-learning & 4.12 & 1.103 & 4.01 & 1.132 \\
\hline
\end{tabular}

Above findings showed that both male and female students scored more or less similar in all the domains of e-learning. It may be due to the present lockdown and Co-vid situation which influence all the students in a same way. The relation with teachers, students, attending classes in virtual medium, unavailability of college resources may show equal impact in every student. So the perception of e-learning of male and female students did not differ significantly. Although it was observed that in the domain perceived ease of use of e-learning the male students scored significantly higher than female students $\left(\mathrm{t}_{[307]}=1.94, \mathrm{p}<0.05\right)$. It may be that male students perceived the skills and technologies to utilize elearning easier than female students. This finding supported the previous findings of Mamattah (2016) and Tagoe (2012) which stated that male students tend to be more active in e-learning than female students. This finding partially supported the first hypothesis $\left(\mathrm{H}_{1}\right)$ that the male undergraduate honours students significantly differed from female counterparts in respect of perceived ease of use of e-learning.

Area was found to be significantly differ $\left(\mathrm{t}_{[307]}=-2.74, \mathrm{p}<0.01\right)$ in the domain perceived ease of use of e-learning where urban students scored higher $(M=23.28, S D=3.68)$ than rural students higher $(M=21.84, S D=4.26)$. This result indicated that the urban students were more comfortable in using E-learning than the rural students. The easy access and availability of the resources in urban areas could be a reason for this finding. This result revealed that rural undergraduate honours students significantly differed from their urban counterparts in respect of perceived ease of use of e-learning, which partially accepted hypothesis two $\left(\mathrm{H}_{2}\right)$.

Facility of mobile phone and laptop or desktop for attending online classes significantly differed in the domain perceived usefulness of e-learning $\left(\mathrm{t}_{[307]}=-4.02, \mathrm{p}<0.01\right)$, perceived ease of use of e-learning $\left(\mathrm{t}_{[307]}=-3.50, \mathrm{p}<0.01\right)$ and intention to use e-learning $\left(\mathrm{t}_{[307]}=-2.07, \mathrm{p}<0.05\right)$. Around $82 \%$ students used mobile phones for accessing the elearning while rest used both mobile and laptop or desktop facilities. It indicated that students who enjoyed these facilities may perceive e-learning more friendly as $44 \%$ students answered e-learning to be online learning. So for this understanding students having mobile phones perceived e-learning easier to handle than those having both facilities. Around $61 \%$ students agreed that e-learning mode provides the flexibility to study at the time convenient to the students and e-learning enables students to study (69\% agreed) irrespective of their location. With the help of technologies it is easy to get the information from web and interact with the teachers without meeting face to face which students found more user-friendly and comfortable and they can utilize self-paced learning. In the study majority of students reported that they want e-learning for studies in future although they liked both online learning and face-toface learning for study. These findings support the hypothesis three $\left(\mathrm{H}_{3}\right)$ on three domains perceived usefulness of elearning, perceived ease of use of e-learning \& intention to use e-learning which stated significant differences between undergraduate honours students who were only mobile phones users \& those who were both mobile phones \& laptops/desktop users for e-learning.

One-way ANOVA was conducted to see the effect of different demographic variables on e-learning. It was found that perceived usefulness of e-learning was significantly influenced by academic year $\left(\mathrm{F}_{[2,306]}=6.18, \mathrm{p}<0.01\right)$ which indicated that students from three different years of graduation perceived the e-learning differently. The first year students scored highest among the three batches which may be e-learning for them is a kind of something new learning and matter of exploration. This finding partially supported the fourth hypothesis $\left(\mathrm{H}_{4}\right)$ that a significant mean difference existed among three academic years in honours undergraduate degree course (i.e. $1^{\text {st }}$ year, $2^{\text {nd }}$ year $\&$ final year) in terms of perceived usefulness of e-learning.

Stream was found to be significantly differ in the domains perceived usefulness of e-learning $\left(\mathrm{t}_{[307]}=3.15, \mathrm{p}<0.05\right)$ and attitude toward using e-learning $\left(\mathrm{t}_{[307]}=3.76, \mathrm{p}<0.05\right)$. Students from Commerce stream scored highest among three streams despite being lowest in number which indicates that they are more interested in e-learning rather than students from science and arts streams. Perceiving e-learning other than online learning (31\% answered on learning by watching pre-recorded videos) could be a reason for such findings. In case of attitude toward using e-learning students 


\section{International Journal of Innovative Research in Science, Engineering and Technology (IJIRSET) \\ | e-ISSN: 2319-8753, p-ISSN: 2320-6710| www.ijirset.com | Impact Factor: 7.512| \\ || Volume 9, Issue 10, October 2020 ||}

from arts stream scored highest which indicates that they received more positive encouragements and feedbacks for using the e-learning than others and they got the positive media reviews also for which they developed a favourable attitude towards e-learning. Results of these findings showed significant differences among three programmes in honours undergraduate degree course (i.e.; Science, Humanities \& Commerce) in three domains of e-learning i.e. perceived usefulness of e-learning, perceived ease of use of e-learning \& attitude towards using e-learning which supported hypothesis five $\left(\mathrm{H}_{5}\right)$.

\section{CONCLUSION}

It can be concluded from the above study that the perception of e-learning were same for both male and female students except the domain perceived ease of use of e-learning. Easy accessibility of resources for e-learning in urban areas made the students user friendly. Students having mobile or laptop or desktop support e-learning as it encouraged the self-paced learning without meeting face-to-face. Students from Commerce background have better perception for elearning whereas students from arts background received more positive feedback and reviews for e-learning.

\section{REFERENCES}

1. Aixia, D., \& Wang, D. (2011). Factors influencing learner attitudes toward e-learning and development of elearning environment based on the integrated e-learning platform. International Journal of eEducation, e-Business, e-Management and e-Learning, 1(3), 264-268. Retrieved May 4, 2013 from http://www.ijeeee.org/Papers/043Z0031.pdf

2. AL-Hunaiyyan, A., Al-Huwail. N., \& Al-Sharhan, S. (2008). Blended e-learning design: Discussion of cultural issues. International Journal of Cyber Society and Education, 1(1), 17-32.

3. Allen, I., \& Seaman, J. (2003). Sizing the opportunity: The quality and extent of online education in the United States, 2002-2003. Needham, MA: Sloan.

4. Anastasiades, P., \&Retalis, S. (2001). The educational process in the emerging information society: Conditions for the reversal of the linear model of education and the development of an open type hybrid leaning environment. Proceedings of ED-MEDIA 2001, Tampere, Finland, June 25-30. 43-50.

5. Andersson, A., \&Grönlund, A. (2009). A conceptual framework for E-learning in developing countries: A critical review of research challenges. The Electronic Journal on Information Systems in Developing Countries, 38(2), 116.

6. Benbunan-Fich, R. \& Starr, R. H. (2003). Mediators of the effectiveness of online courses. IEEE Transactions on Professional Communication, 46(4), 296-312.

7. Bertea, P. (2009). Measuring students' attitude towards e-learning: A case study. Proceedings of 5th International Scientific Conference on e-Learning and Software for Education, Bucharest, April 9th-10th.

8. Bhattacharjee, B. (2008). Factors affecting computer use among older adult users: A study in the backdrop of the Florida State University. PhD Thesis, College of Information, The Florida State University. Retrieved May 5, 2013 from http://diginole.lib.fsu.edu/cgi/viewcontent.cgi? article $=2284 \&$ context $=$ etd

9. Bhuasiri, W., Xaymoungkhoun, O., Zo, H., Rho, J, J., \&Ciganek, A, P. (2012). Critical success factors for elearning in developing countries: A comparative analysis between ICT experts and faculty. Computers \& Education, 58 (2012), 843-855.

10. Busch, T. (1995). Gender differences in self-efficacy and attitudes toward computers. Journal of Educational Computing Research, 12(2), 147-158.

11. Buzzetto-More, N., 2015. Student attitudes towards the integration of youtube in online, hybrid, and web-assisted courses: An examination of the impact of course modality on perception. MERLOT Journal of Online Learning and Teaching Vol. 11, No. 1, March 2015. Retrieved November 10, 2015 from http://jolt.merlot.org/vol11no1/BuzzettoMore_0315.pdf

12. Chiu, C. M., \& Wang, E. T. G. (2008). Understanding web-based learning continuance intention: The role of subjective task value. Information \& Management, 45(3), 194-201.

13. Clark, R. C., \& Mayer, R. E. (2003). E-learning and the science of instruction. San Francisco: Jossey-Bass.

14. Davis, F. D., Bagozzi, R. P. \&Warshaw, P. R. (1989). User acceptance of computer technology: A comparison of two theoretical models. Management Science, 35(8), 982- 1003. http://www.jstor.org/pss/2632151

15. Docebo (2014). E-Learning market trends \& forecast 2014 - 2016 report. Retrieved January 24, 2015 from https://www.docebo.com/landing/contactform/elearning-market-trendsand-forecast-2014-2016-docebo-report.pdf

16. Grandon, E., Alshare, O., \& Kwan, O. (2005). Factors influencing student intention to adopt online classes: A cross-cultural study. Journal of Computing Sciences in Colleges, 20(4), 46-56. 
17. Golladay, R., Prybutok, V. \& Huff, R. (2000). Critical success factors for the online learner. Journal of Computer Information Systems, 40(4), 69-71.

18. Hara, N. \& Kling, R. (2000). Students' distress with a web-based distance education course: An ethnographic study of participants' experiences. Information, Communication and Society, 3(4), 557-579.

19. Hrastinski, S., (2008). A study of asynchronous and synchronous e-learning methods discovered that each support different purposes. Retrieved March 27, 2015 from http://net.educause.edu/ir/library/pdf/eqm0848.pdf.

20. Jung, M., Loria, K., Mostaghel, R \&Saha, P. (2008). E-learning: Investigating university students' acceptance of technology. European Journal of Open, Distance and E-Leaning. Retrieved January 28, 2015 from http://www.eurodl.org./materials/contrib/2008/Jung_Loria_Mostaghel_Saha.htm

21. Kalpana, V. (2010). Future Trends in E-Learning. IEEE 2010 4th International Conference on Distance Learning and Education (ICDLE).

22. Kelly, T., \& Bauer, D. (2004). Managing intellectual capital via e-learning at Cisco. In C. Holsapple (Ed.), Handbook on knowledge management 2: Knowledge directions (pp. 511-532). Berlin, Germany: Springer.

23. Kiraz, E. \&Ozdemir, D. (2006). The relationship between educational ideologies and technology acceptance in pre-service teachers. Educational Technology and Society, 9(2), 152-165. http://www.ifets.info/journals/9 2/13.pdf

24. Kocur, D., \&Kosc, P., (2009). E-learning Implementation in Higher Education. Acta_Electrotechnica et Informatica, Vol. 9, No. 1, pp20-26

25. Koohang, A. \& Harman, K. (2005). Open source: A metaphor for e-learning. Informing Science Journal Volume 8, 2005.

26. Laine, L. (2003). Is e-learning effective for IT training? T $+\mathrm{D}, 57(6), 55-60$.

27. Lee, B.C., Yoon, J.O., \& Lee, I (2009). Learners' acceptance of e-learning in South Korea: Theories and results. Computers \& Education 53 (2009) 1320-1329. Retrieved 27 March 2015 from: http://www.sciencedirect.com/science/article/pii/S0360131509001614

28. Lee, C., \&Witta, L. (2001). Online students' perceived self-efficacy: Does it change? Paper presented at the national convention of the Association for Educational Communications and Technology, Atlanta, GA.

29. Lorenzetti, J. (2005). Lessons learned about student issues in online learning. Distance Education Report, 9(6), 1-4.

30. Loyd, B. H., \&Gressard, C. (1984). The effects of sex, age, and computer experience on computer attitudes. AEDS Journal, 18(2), 67-77.

31. Masrom, M. (2007). Technology acceptance model and e-learning. In: 12th International Conference on Education, 21-24 May 2007, Sultan HassanalBolkiah Institute of Education, University Brunei Darussalam http://eprints.utm.my/5482/1/MaslinMasrom2006_Techn.pdf

32. McDonald, D. (1999-2000). Improved training methods through the use of multimedia technology. Journal of Computer Information Systems, 40(2), 17-20.

33. McEwen, T. (1997). Communication training in corporate settings: Lessons and opportunities for the academe. Mid-American Journal of Business, 12(1), 49-58.

34. McGreal, R., \& Elliott, M. (2004). Technologies of online learning (e-learning). In T. Anderson, \& F. Elloumi, Theory and practice of online learning, (pp. 115-135). Athabasca University.

35. McKeachie, W. (2002). McKeachie's Teaching Tips: Strategies, Research, and Theory for College and University Teachers (11th ed.). Boston, MA: Houghton Mifflin.

36. McKinnon, K. \&Igonor, A. (2008). Explaining eLearning perceptions using the Technology Acceptance Model and the Theory of Planned Behavior. In C. Bonk et al. (Eds.), Proceedings of World Conference on E-Learning in Corporate, Government, Healthcare, and Higher Education 2008.

37. Nassoura, A. B. (2012). Students' acceptance of mobile learning for higher education in Saudi Arabia. American Academic \& Scholarly Research Journal, 4(2). Retrieved January 20, 2013 from http://aasrc.org/aasrj/index.php/aasrj/article/download/248/188

38. Nov, O. \& Ye, C. (2008). Users' personality and perceived ease of use of digital libraries: The case for resistance to change. Journal of the American Society for Information Science and Technology, 59(5), 845-851. http://dx.doi.org/10.1002/asi.20800

39. Obasa, A. I. (2010). The development of an integrated virtual classroom. M. Tech thesis, Federal University of Technology, Akure, Nov.2010.

40. Obasa, A. I., Eludire, A. A. \&Ajao, T. A., (2013). A comparative study of synchronous and asynchronous Elearning resources. International Journal of Innovative Research in Science, Engineering and Technology (IJIRSET), Vol. 2, Issue 11, November 2013.

41. Oh, E., \& Park, S. (2009). How are universities involved in blended instruction? Educational Technology \& Society, 12(3), 327-342. 
42. Omidinia, S., Masrom, M., \&Selamat, H. (2011). Review of e-learning and ICT infrastructure in developing countries (Case study of Iran). American Journal of Economics and Business Administration, 3(1), 120-125. Retrieved January 22, 2013 from http://thescipub.com/pdf/10.3844/ajebasp.2011.120.125

43. Ong, C. S., \& Lai, J. Y. (2006). Gender differences in perceptions and relationships among dominants of e-learning acceptance. Computers in Human Behavior, Vol. 22, pp.816- 829.

44. Paris, P, G. (2004). E-learning: A study on secondary students' attitudes towards online web assisted learning. International Education Journal, 5(1), 98-112. Retrieved May $1, \quad 2013$ from http://ehlt.flinders.edu.au/education/iej/articles/v5n1/paris/paper.pdf

45. Park, S. Y. (2009). An Analysis of the Technology Acceptance Model in Understanding University Students' Behavioral Intention to Use e-Learning. Educational Technology \& Society, 12 (3), 150-162.

46. Piccoli, G., Ahmad, R. \& Ives, B. (2001). Web-based virtual learning environments: A research framework and a preliminary assessment of effectiveness in basic IT skills training. MIS Quarterly, 25(4), 401-425.

47. Raymond SelormMamattah. Students' Perceptions of E-Learning; Linköping University |Department of Behavioural Sciences and Learning Master program Adult Learning and Global Change, 60 credits Spring $2016 \mid$ ISRN-number: LIU-IBL/IMPALGC-A - 16/005-SE

48. Rubenstein, H. (2003). Recognizing e-learning's potential \& pitfalls. Learning \& Training Innovations 4(4), 38.

49. Ryan, S. (2001). Is online learning right for you? American Agent \& Broker, 73(6), 54-58.

50. Schumacher, P., \&Morahan-Martin, J. (2001). Gender, internet and computer attitudes and experiences. Computers in Human Behavior, 17(1), 95-110.

51. Sehrt, M. (2003). E-learning in the developing countries - Digital divide into digital opportunities. UN Chronicle Online, 4(3), 45-46.

52. Selim, H. M. (2003). An empirical investigation of student acceptance of course web sites. Computers \& Education, 40, 343-360.

53. Serwatka, J. (2003). Assessment in on-line CIS courses. Journal of Computer Information Systems, 43(3), 16-20.

54. Siragusa, L., \& Dixon, K. (2008). Planned behaviour: Student attitudes towards the use of ICT interactions in higher education. In Hello! Where are you in the landscape of educational technology? Proceedings ascilite $\begin{array}{llllll}\text { Melbourne } & 2008 . & \text { Retrieved } & \text { May } & \text { 3, } & \text { from }\end{array}$ http://www.swaraunib.com/indra/Sistem\%20informasi/TPB/siragusa.pdf

55. Smart, K. L., \&Cappel, J. J. (2006). Students' perceptions of online learning: A comparative study. Journal of Information Technology Education, Volume 5, 2006. Retrieved November 9, 2015 from http://jite.org/documents/Vol5/v5p201-219Smart54.pdf

56. Suri, G., \& Sharma, S. (2013). The impact of gender on attitude towards computer technology and elearning: An exploratory study of Punjab University, India. International Journal of Engineering Research, 2(2), $132-136$. Retrieved May 31, 2013 from http://www.ijer.in/ijer/publication/v2s2/paper22.pdf

57. Tagoe, M. (2012). Students' perceptions on incorporating e-learning into teaching and learning at the University of Ghana. International Journal of Education and Development using Information and Communication Technology (IJEDICT), 2012, Vol. 8, Issue 1, pp. 91-103.

58. Taylor, S., and Todd, P. 1995. “Assessing IT Usage: The Role of Prior Experience,” MIS Quarterly (19:4), pp. 561-570.

59. Teo, T. (2009). Modelling technology acceptance in education: A study of pre-service teachers. Computers \& Education, 52(2), 302-312. http://dx.doi.org/10.1016/j.compedu.2008.08.006

60. Venkatesh, V., \& Davis, F. D. (1996). A model of the antecedents of perceived ease of use: Development and test. Decision Sciences, 27, 451-481.

61. Ward, J. \&LaBranche, G. (2003). Blended learning: The convergence of e-learning and meetings. Franchising World, 35(4), 22-23.

62. Welsh, E., Wanberg, C., Brown, K. \& Simmering, M. (2003). E-learning: emerging uses, empirical results and future directions. International Journal of Training and Development, Vol. 7, No. 4, pp.245-258.

63. Yi, M. \& Hwang, Y. (2003). Predicting the use of web-based information systems: Selfefficacy, enjoyment, learning goal orientation, and the technology acceptance model. International Journal of Human-Computer Studies, 59, 431-449. http://dx.doi.org/10.1016/S1071-5819(03)00114-9

64. Young, B., Hausler, J., \& Sanders, J. (2008). Do online students exhibit different learning styles than onsite students? International Journal of Instructional Technology and Distance Education, 5(4). Retrieved November 10, 2015 from http://www.itdl.org/Journal/Apr_08/article02.htm

65. Young, J. (2002). "Hybrid" teaching seeks to end the divide between traditional and online instruction. Chronicle of Higher Education, 48(28), A33. 
